\title{
PKM Pelatihan Praktik Melukis Teknik Fresco Bagi Murid dan Guru Di Sekolah Dasar INPRES Unggulan BTN. Pemda Makassar
}

\author{
Muhammad Saleh Husain ${ }^{1}$, Sofyan Salam², Aswar ${ }^{3}$ \\ ${ }^{1,2,3}$ Fakultas Seni dan Desain, Universitas Negeri Makassar
}

\begin{abstract}
Presentation of material on the learning process of art education theory and art education practicum, whose behavior is directed at the method of presenting aesthetic concepts, creativity and work, adjusted to the level of ability of the students themselves. The connection in this case is to avoid the passivity of students during the learning process of fine arts education, through the presentation of educational media applied by the teacher will be a motivation to think creatively to apply freedom of exploration and freedom to express feelings and create real work in creating works. works of art in accordance with the structured assignment of subject matter from the teacher. The trend towards increasing teaching of fine arts education will benefit from being presented to formal educational institutions in an academic manner that is implemented at BTN's Inpres Featured Primary School. The local government of Makassar, regarding the learning process which has an innovative direction, both in the form of a presentation of basic theories and the practice of working in fine arts is quite a lot marked through the form of a teaching process that provides space for creativity, exploration, learning to work in Fresco technique painting, which of course begins with drawing learning exercises. sketches applied to students and teachers of the Inpres Unggulan BTN Elementary School. Pemda Makassar, so that students will experience a change from not knowing to knowing, through growth in attitudes and growth in thinking increasingly creative and intelligent.
\end{abstract}

Keywords: PKM, Training, Practice, Painting, Fresco.

\section{PENDAHULUAN}

Untuk memperoleh keberhasilan yang ingin dicapai bagi guru kesenian (seni rupa) dalam proses belajar mengajar, maka guru tersebut harus menyadari adanya kemampuan melakukan pengetahuan dan aplikasinya tentang ilmu-ilmu didaktik proses sajian pembelajaran Sekolah Dasar, dalam hal ini diupayakan memiliki wawasan ilmu berdasarkan teori dan praktikum seni rupa, memiliki sifat rasa asih dan asuh terhadap muridmurid, dan yang lebih utama adalah guru kesenian (seni rupa) memiliki kompetensi yang tepat melaksanakan tugasnya, maka dalam hal ini guru akan dapat dengan mudah melaksanakan pekerjaannya dengan baik.

\section{Tujuan Belajar Pendidikan Seni Rupa}

Setelah mempelajari dengan seksama, mengenai belajar pendidikan seni rupa di Sekolah, melalui alat bantu mengajar sebagai media pembelajaran pendidikan seni rupa, diharapkan guru dan murid akan memperoleh sejumlah kompetensi dasar untuk memudahkan terapan di dalam proses belajar mengajar. Proses pembelajaran pendidikan seni rupa sebagai usaha mencapai tujuan pendidikan berlangsung dalam suatu proses pembelajaran untuk mengalihkan pengetahuan yang erat dengan kandungan estetika, artistik, sikap dan keterampilan terhadap peserta didik di Sekolah Dasar Inpres Unggulan BTN. Pemda Makassar, kegiatan pembelajaran seni rupa di Sekolah tersebut juga disajikan adanya keseimbangan sajian materi proses pembelajaran teori pendidikan seni rupa dan praktikum pendidikan seni rupa, yang gerak prilakunya diarahkan pada metode proses sajian konsepkonsep estetika, berkreativitas dan berkarya, disesuaikan dengan tingkat kemampuan peserta didik itu sendiri. 
Kaitannya dalam hal ini, untuk menghindari kepasifan murid-murid selama dalam proses belajar pendidikan seni rupa, melalui sajian media pendidikan yang diterapkan oleh guru akan menjadi motivasi berfikir kreatif untuk menerapkan kebebasan eksplorasi dan kebebasan mengekspresikan perasaannya dan mewujudkan hasil karya nyata di dalam mencipta karya-karya seni rupa yang sesuai penugasan materi pelajaran terstruktur dari gurunya. Kecenderungan terhadap meningkatnya pengajaran pendidikan seni rupa akan memperoleh manfaatnya yang disajikan pada lembaga pendidikan formal secara akademik yang diterapkan di Sekolah Dasar Inpres Unggulan BTN. Pemda Makassar, mengenai proses pembelajaran yang arahnya inovatif, baik dalam bentuk sajian teori mendasar dan praktik berkarya seni rupa cukup banyak ditandai melalui bentuk proses pengajaran yang memberi ruang untuk berkreativitas, bereksplorasi, yang diterapkan terhadap murid-murid Sekolah Dasar Inpres Unggulan BTN. Pemda Makassar, sehingga muridmurid akan mengalami perubahan dari tidak tahu menjadi tahu, melalui pertumbuhan pada sikap prilaku dan pertumbuhan berpikirnya semakin kreatif dan cerdas. memperoleh keberhasilan yang ingin dicapai bagi guru kesenian (seni rupa) dalam proses belajar mengajar, maka guru tersebut harus menyad adanya kemampuan melakukan pengetahuan dan aplikasinya tentang ilmu-ilmu didaktik proses sajian pembelajaran Sekolah Dasar Inpres Unggulan BTN. Pemda Makassar, dalam hal ini diupayakan memiliki wawasan ilmu berdasarkan teori dan praktikum seni rupa, memiliki sifat rasa asih dan asuh terhadap siswasiswa, dan yang lebih utama adalah guru kesenian (seni rupa) memiliki kompetensi yang tepat melaksanakan tugasnya, maka dalam hal ini guru akan dapat dengan mudah melaksanakan pekerjaannya dengan baik. Agar para guru kesenian (seni rupa) mampu melaksanakan tugasnya di dalam proses belajar mengajar diperlukan pencapaian indikator sebagai berikut:

\section{METODE YANG DIGUNAKAN}

Kemampuan Belajar Pendidikan Seni Rupa
1. Mampu menjelaskan tujuan yang ingin dicapai di dalam proses belajar mengajar sajian pendidikan seni rupa.

2. Mampu menjelaskan fungsi berbagai media pembelajaran pendidikan seni rupa yang diperlihatkan pada murid.

3. Mampu menjelaskan hakikat yang dicapai bagi siswa setelah belajar mengikuti proses belajar mengajar, baik berupa kegiatan teori maupun praktikum pendidikan seni rupa.

4. Mampu mengembangkan kreativitas penciptaan berkarya seni rupa terhadap siswa, setelah mengikuti proses pembelajaran.

5. Mampu mengapresiasi hasil karya murid, setelah mengikuti proses belajar melalui pengembangan berbagai media pendidikan seni rupa yang diajarkan.

6. Mampu memperagakan proses penggarapan berkarya seni rupa oleh guru kesenian (seni rupa) dan dilihat langsung oleh murid-murid.

7. Mampu menjelaskan tujuan yang ingin dicapai di dalam proses belajar mengajar pendidikan seni rupa.

8. Mampu menjelaskan fungsi berbagai media pembelajaran pendidikan seni rupa yang diperlihatkan pada murid.

9. Mampu mengembangkan kreativitas penciptaan berkarya seni rupa terhadap siswa, setelah mengikuti proses pembelajaran pendidikan seni rupa.

10.Mampu mengapresiasi hasil karya seni rupa yang dibuat oleh murid, setelah mengikuti proses belajar melalui pengembangan berbagai media yang diajarka

\section{Pendekatan pengertian seni:}

Memperbincangkan masalah seni, tidak terlepas dari faktor adanya keindahan, karena seni itu sendiri memperbincangkan masalah keindahan, meskipun yang diperbincangkan tentang keindahan itu sendiri juga belum tentu menyentuh tentang adanya nilai-nilai kandungan seni. Sehingga muncullah pertanyaan, apa sebenarnya kesenian dan keindahan itu?

Memahami keindahan secara sederhana dapat dijelaskan sebagai berikut: 
Kesenian: sebagai ungkapan dan pernyataan rasa estetik yang merangsangnya sejalan dengan pandangan, apresiasi, kebutuhan, dan gagasangagasan yang mendominasinya. Cara- cara pemuasan terhadap kebutuhan estetik itu ditentukan secara budaya seperti aspek-aspek kebudayaan lainnya, Proses pemuasan kebutuhan estetik berlangsung dan diatur oleh seperangkat nilai dan asas yang berlaku dalam Masyarakat dan oleh karena itu cenderung untuk direalisasikan dan diwariskan pada generasi berikutnya. (Rohidi,....; ....)

Keindahan: adalah suatu rangsangan (stimulisasi) yang timbul di dalam hati, sesuatu yang tampak ditangkap oleh indera mata, telinga dan memiliki daya goda diterima oleh otak dan dilanjutkan kehati (rokhaniah), baik dari dalam maupun dari luar yang dapat membangkitkan rasa kagum, senang, mempesona, haru. Sehingga berdasarkan pengalaman seorang seniman menghasilkan karyakarya seni yang diproses melalui hasil kerja hati, otak dan keterampilannya (Skill).

Keindahan sifatnya relatif, artinya tidak mutlak karena tidak ada norma atau ukuran tertentu sebagai ukuran batasan keindahan, setiap orang tidak sama memberikan pernyataan ukuran tentang keindahan yang dinikmatinya. Hal ini tergantung pada sudut pandang (paradigma) seseorang menikmati peristiwa prilaku manusia yang melakukan kegiatan kesenian, atau adanya panorama alam yang memiliki karakter nilai muatan keindahan. Dipastikan setiap orang memiliki kemampuan tingkat rasa keindahan (Estetic Cencitivity) yang berbeda-beda.

\section{PELAKSANAAN DAN HASIL KEGIATAN}

\section{Berkreasi Dalam Seni Rupa Dua Dimensi}

Belajar berkarya seni rupa 2 dimensi dalam bentuk menggambar diperlukan adanya keberanian berkreasi, pada halaman terdahulu sudah diuraikan mengenai dasar teori mengenal tentang adanya macam garis dan mengenal warna. Kegairahan belajar menggambar akan lebih lengkap jika juga belajar terapan mewarna hasil gambar yang sudah dibuat. Dari terbitan buku- buku yang menuntun mudahnya belajar menggambar demikian banyaknya berbagai metode yang disajikan, melalui mengenal garis (garis lurus, garis patah dan garis lengkung) dapat dikembangkan membentuk hasil gambar dengan berlatih menggores secara berulang- ulang. Bentuk gambar yang dibuat bebas, dapat diawali dengan alam benda yang berbentuk peti, lemari atau kotak tentu diawali menggunakan bentuk kubus dengan menerapkan garis lurus dan garis patah, demikian juga jika belajar menggambar alam benda yang berbentuk bola, ember, botol, baskom, tempayan tentu diawali menggunakan bentuk lingkaran, bulat lonjong (elief) dengan menerapkan garis lengkung dan garis lurus. Mengenai bentuk alam benda yang akan digambar dengan sendirinya dapat diikuti model bentuk dari benda yang dilihatnya.

Selanjutnya jika ingin berkembang mempelajari menggambar bentuk alam benda lainnya misalnya bentuk kendaraan, macam- macam binatang, macam- macam tanaman dan objek manusia. Dengan sendirinya harus memperhatikan terlebih dahulu bentuk objeknya, kemudian melalui terapan garis dapat diterjemahkan bentuk objek yang diamati, dibuat dalam bentuk gambar berupa bagan atau sketsa, untuk mencapai tingkat sempurnanya bentuk hasil gambar yang dibuat haruslah tekun belajar terus menerus agar keterampilan tangannya menggores lebih cekatan. Pada saat belajar selayaknya dihindari menggunakan alat mistar, keberanian menggores sangatlah diperlukan, kesabaran dan kesungguhan belajar menjadi prioritas utama. Malaui seringnya berlatih belajar menggambar olah rasa, ketajaman melihat objek, keterampilan tangan akan terbentuk dengan sendirinya, sehingga pekerjaan menggambar akan menjadi kemudahan untuk dilakukan.

Latar belakang yang dikemukakan dalam buku mata pelajaran pendidikan seni budaya, mengulas pandangan teorinya:

Untuk belajar menggambar maka harus belajar merasakan kehadiran benda yang akan dijadikan objek. Dalam menggambar secara konstan kita memindahkan objek yang kita lihat ke dalam bentuk simbol dan mengingatnya. Tidak ada garis di dalam alam. Bila kita merasakan bentuk sebuah 
objek, kita harus menyadari bahwa objek itu dalam bentuk tiga dimensi. Hanya dengan penerjemahan ke dalam istilah tepi linier serta dengan nilai- nilai gelap terang kita bisa menyampaikan atau mengungkapkan perasaan kita dalam suatu bentuk di atas kertas. (Yoyok RM.dan Siswandi, 2007:20)

Melalui sajian ulasan penulisan modul belajar mengenal pendidikan seni rupa untuk pelaksanaan Pengabdian Pada Masyarakat Universitas Negeri Makassar, penulis terlebih dahulu menjelaskan teori tentang pengertian terapan teknik seni lukis:

Seni lukis yaitu, Karya yang dihasilkan melalui goresan warna yang relatif berukuran lebar, yang dihasilkan menggunakan alat kuas, pisau palet, tabung pilox, telapak tangan dan jari tangan, dengan menerapkan bahan berbagai pewarna. (Salam, 2001:4)

Seni Lukis Fresco yaitu, teknik melukis pada dinding dengan menimpakan pigmen pada plaster dinding yang baru dilapisi, kemudian definisi ini sedikit berubah karena Leonardo da Vinci memperkenalkan teknik baru dengan menimpakan pigmen warna kepada lapisan yang telah kering dengan sedikit modifikasi. (https//www.dicto id. teknik melukis al fresco, 3 April 2018).

Jika memahami pengertian lukis teknik fresco setelah mengalami perubahan oleh Leonardo da Vinci memperkenalkan teknik baru dengan menimpakan pigmen warna pada lapisan dinding yang kering dengan sedikit modifikasi, maka yang lazim dilakukan oleh pelukis kalangan generasi muda biasa menerapkan di dinding-dinding Gedung atau pinggiran lorong dengan melukis mural. Perencanaan tampilan seni lukis teknik Fresco yang akan dibuat di sekitar halaman Sekolah, berdasarkan kesepakatan pihak Kepala Sekolah dan Guru bidang studi Seni Budaya (Seni Rupa), maka gambaran sketsanya sebagai berikut:

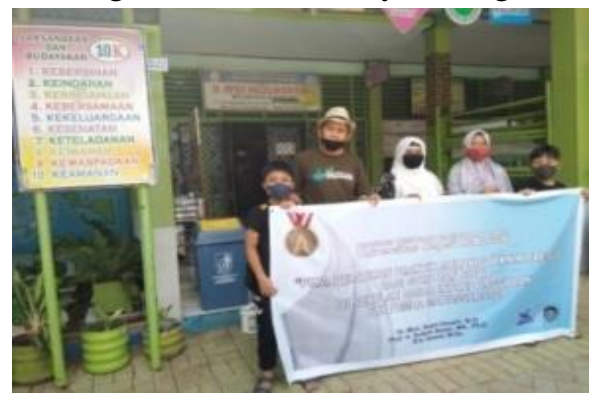

Instruktur ( Dr.Muh.Saleh Husain, M.Si)

bersama Wakil Kepala Sekolah,murid di depan Kantor kepala Sekolah

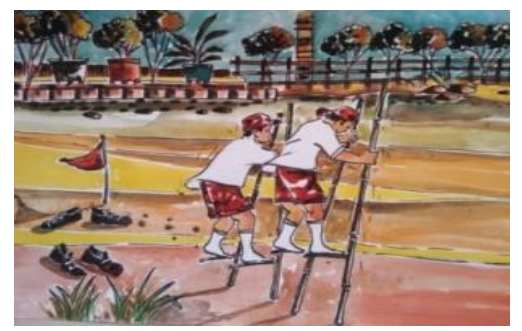

Bidang 1.Gambaran dinding Sekolah yang akan diisi lukisan Mural / Fresco

Bidang 1: bagian bidang ini menggambarkan permainan tradisional masyarakat Indonesia, yang disemua wilayah Nusantara di Indonesia permainan "Egrang" ini merupakan permainan yang dilestarikan, tentang istilah nama jenis permainan ini dimasing-masing wilayah juga berbeda-beda namanya, tergantung bahasa daerah dilokasinya masing-masing, intinya permainan ini bahan yang dipakai dari bahan batang bambu yang dibuat beradasarkan ukuran sesuai kebutuhan bagi sipemakai, permainan ini tidak mudah bagi orang yang belum pernah melakukannya, diperlukan keseimbangan tubuh, karena kekuatan dua kaki yang menumpu tubuh untuk dapat berdiri, posisi dalam keadaan diam di tempat, bergerak maju dan bergerak mundur jika sudah menguasai keseimbangan tubuh selanjutnya dapat melakukan dengan berjalan bahkan berlari pelan maupun berlari cepat, bahkan juga dapat bergerak dengan menari - nari bagian tubahnya, hanya tubuh karena dua tangan sedang memegang batang bambu dan dua kaki sedang menumpu di atas batang tumpuan kaki juga dari bahan bambu.

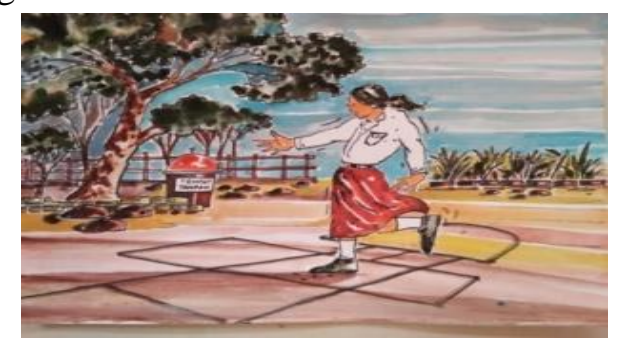

Bidang 2 Sketsa Gambar murid sedang bermain dende-dende 


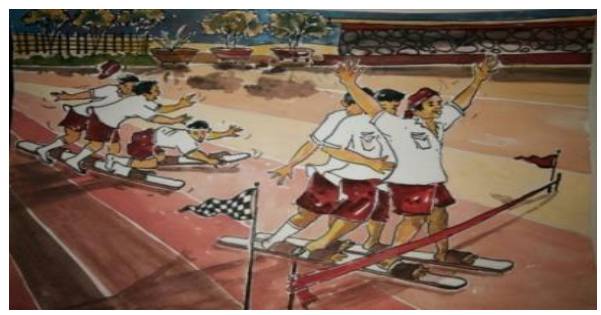

Bidang 3 Sketsa Gambar Siswa sedang bermain "Terompa"

Bidang 2: bagian bidang ini menggambarkan permainan tradisional masyarakat Indonesia, yang disemua wilayah Nusantara di Indonesia permainan "Dende - Dende " ini merupakan permainan yang dilestarikan, tentang istilah nama jenis permainan ini dimasing-masing wilayah juga berbeda-beda namanya, tergantung bahasa daerah dilokasinya masing-masing, intinya permainan ini umumnya dilakukan oleh anak-anak perempuan, permaian "Dende- Dende" terlebuh dahulu dibuat melalui garis gambar bidang petak-petak dan setengah lingkaran, tempat bermainnya tergantung keadaan dari lahan yang tersedia, biasanya di halaman depan rumah di atas permukaan tanah, di lantai halaman rumah, alat perlengkapan bermain satu serpihan tembikar. Dalam melakukan permainan ini juga diperlukan keseimbangan tubuh, karena kekuatan satu kaki yang menumpu tubuh untuk dapat berdiri, posisi dalam keadaan diam di tempat, bergerak maju dengan melompat dari satu petak ke petak yang lain, permainan termasuk menguji keterampilan bergerak dengan melompat- lompat dengan satu kaki dan juga keterampilan melempar serpihan tembikar tepat di tengah-tengah petak yang ditentukan, jika pada saat melompat kaki menginjak garis dari petak yang dilompati atau lemparan serpihan tembikar tidak tepat pada tempat yang dikehendaki maka permainan dianggap gugur dan harus berhenti. Kemudian permainan digantikan oleh lawan bermain. Permainan ' Dende - Dende " dinyatakan sebagai pemenang jika, dapat melompati setiap petak dengan melemparkan serpihan tembikar kesetiap petak dengan tepat, dari petak satu, petak dua, petak tiga, petak satu, petak dua dan kepetak setengah lingkaran, demikian kembali lagi melompati ke petak-petak menuju kepetak satu.
Bidang 3: Bagian bidang ini menggambarkan permainan tradisional masyarakat Indonesia, yang disemua wilayah Nusantara di Indonesia permainan " Terompa " ini merupakan permainan yang dilestarikan, tentang istilah nama jenis permainan ini dimasing-masing wilayah juga berbeda-beda namanya, tergantung bahasa daerah dilokasinya masing-masing, intinya permainan ini bahan yang dipakai dari bahan batang kayu (papan kayu) yang dibuat berbentuk terompa panjang yang ukurannya relatif tergantung dari jumlah orang yang bermain dalam satu tim (satu kelompok), papan yang dibuat berbentuk terompa, permainan ini tidak mudah bagi orang yang belum bisa kompak pada saat melangkahkan dua kakinya berjalan secara bergantian, permainan ini diperlukan latihan, karena ukurannya panjang, maka jumlah pemainnya biasanya lebih dari dua orang. Permainan ini diperlukan keseimbangan tubuh dengan ayunan kaki yang sama, jika yang paling depan mengayunkan kaki sebelah kanan maka orang dibelakangnya sejumlah satu tim harus melakukan dengan ayunan kaki kanan dengan bersamaan, begitu juga mengayunkan kaki sebelah kiri, layaknya orang berjalan bahkan berlari secara bersama - sama dengan kaki yang diselipkan pada pengikat terompa. Intinya dalam permainan ini gerakannya hanya bergerak berjalan cepat dengan langkah-langkah yang kompak, jika salah satu orang dalam satu tim salah mengayunkan langkah kaki maka akan terjadi tidak seimbang dan dipastikan jatuh bersama-sama dalam satu tim. Permainan inilah yang menjadi menarik dan menghibur pada saat beradu siapa yang tercepat bergerak melangkah menuju batas jarak yang ditentukan.

\section{Evaluasi Hasil Belajar yang Dicapai:}

Pelaksanaan workshop pelatihan tentang belajar menggambar sketsa dan dilanjutkan pada berkarya lukis teknik Fresco yang disajikan pada murid dan ibu guru Sekolah Dasar Inpres Unggulan BTN Pemda Makassar dalam sajian Pengabdian Pada Masyarakat diuraikan sebagai berikut:

Para murid Sekolah Dasar Inpres Unggulan BTN Pemda Makassar setelah disajikan materi belajar menggambar sketsa bentuk bebas dan 
bentuk huruf, dapat mengetahui metode mudahnya belajar menggambar, mengenai menggambar diawali membuat bentuk angka-angka nol sampai sembilan. Sebagai pengantar sebelum menggambar diperkenalkan karakter garis, yang mana garis terdiri atas tiga macam karakter yaitu garis lurus, garis lengkung dan garis patah. Jika mengamati bentuk arah garis dari angka nol sampai angka sembilan, maka masing-masing mengarah pada bentuk karakter garis lurus, patah dan lengkung. Contoh angka satu (1) berbentuk garis lurus tegak, angka dua (2) berbentuk garis lengkung lurus, angka tiga (3) berbentuk garis lengkung, angka empat (4) berbentuk garis patah, demikian juga pada angka-angka berikutnya. Kelengkapan yang diperlihatkan sebagai capaian hasil belajar dan evaluasinya dapat dilihat gambar foto hasil aktivitas Guru dan murid belajar menggambar melalui metoda angka-angka sebagai berikut:

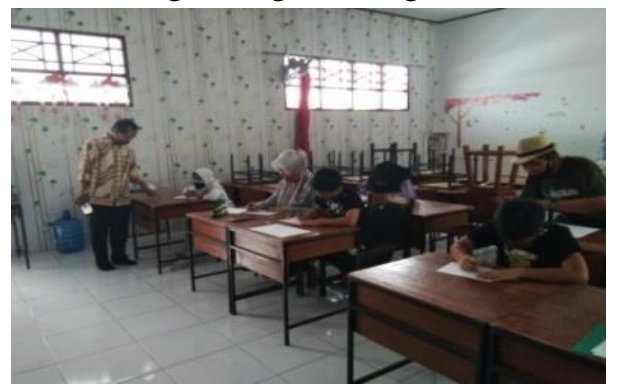

Instruktur (Drs.Aswar, M.Ds) mengarahkan pada murid saat belajar praktik menggambar sketsa dasar- dasar menggambar

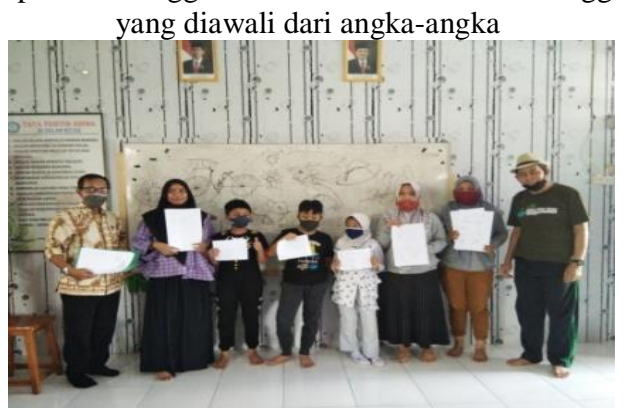

Instruktur, Guru dan murid berpose pada saat berakhir belajar menggambar semut, kupu-kupu, becak, ikan, sandal udang dan cumi-cumi

Hasil capaian murid belajar praktik menggambar setelah menyimak sajian wawasan teori dan peragaan praktik hidup metode menggambar sketsa sebagai berikut:

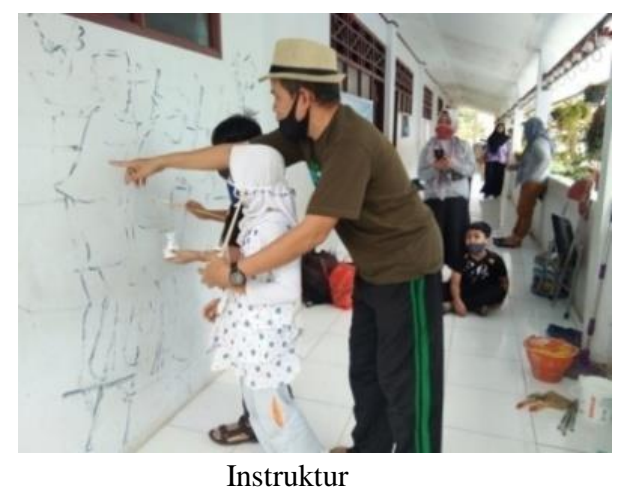

(Dr. Muh.Saleh Husain, M.Si)

menunjukkan pada Murid mengecat dinding bagian gambar baju

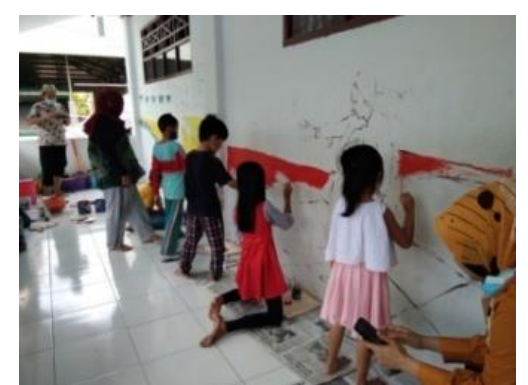

Instruktur Dr.Muh.Saleh Husain,M.Si) Sedang mengarahkan membimbing Murid-murid mengecat dinding melukis fresco

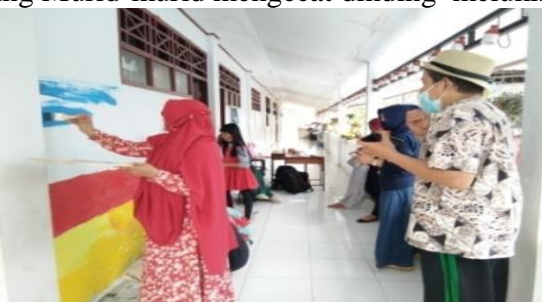

Instruktur (Dr.Muh.Saleh Husain,M.Si) Sedang mengarahkan membimbing Ibu Guru mengecat dinding melukis fresco

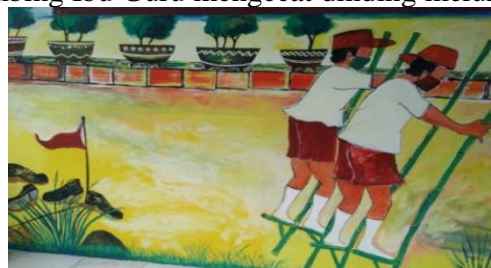

Hasil lukisan Fresco yang dicapai murid dan ibu Guru

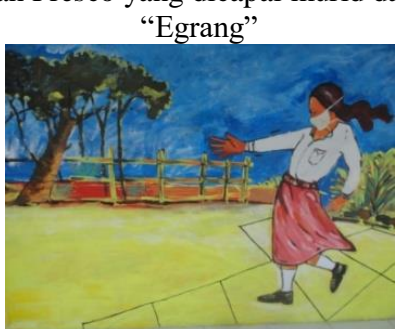

Hasil lukisan Fresco yang dicapai murid dan guru "DendeDende" 


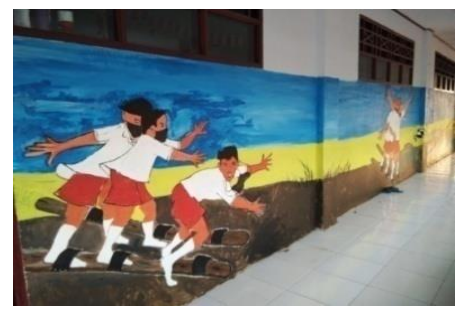

Hasil lukisan Fresco murid dan guru melukiskan lomba terompa "Kalah"

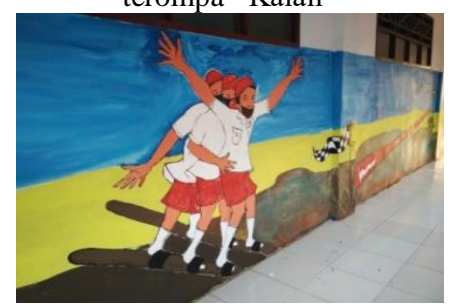

Hasil lukisan Fresco murid dan guru melukiskan lomba terompa "Menang"

\section{Faktor Pendorong}

1. Pelatihan pembelajaran membuat karya gambar Sketsa dasar angka Nol sampai angka Sembilan dan mewarna teknik blok mengecat dinding sebagai media lukis teknik Fresco.

2. Guru dan murid Sekolah Dasar Inpres Unggulan BTN Pemda Makassar dapat meningkatkan kompetensi Guru dalam pembuatan media pembelajaran seni rupa.

3. Guru dan para murid Sekolah Dasar Inpres Unggulan BTN Pemda Makassar dapat lebih produktif berlatih praktik berkarya keterampilan menggambar sketsa dan melukis teknik Fresco.

\section{Faktor Peoghambat}

Di Sekolah. Dasar Inpres Unggulan BTN Pemda Makassar pengampu mata pelajaran Seni Budaya bagi Guru Kelas mengajar Seni Rupa belum mengenal pengetahuan teori tentang mudahnya belajar menggambar sketsa dan dilanjutkan ke melukis teknik Fresco. Kendala inilah yang berpengaruh bagi peserta didik dengan sajian materi pelajaran seni rupa, maka pada saat pelatihan dalam kegiatan workshop pelaksanaan Pengabdian Pada Masyarakat Universitas Negeri Makassar perlu membantu menyajikan sesuai dengan kapasitasnya, yaitu perlunya dibantu untuk diperkenalkan bagaimana yang sebenarmya belajar seni rupa terutamamateri menggambar sketsa hingga kemelukis teknik Fresco, namun demikian kendala lainnya juga penggunaan waktu pelatihan yang sangat minim, hal ini dikarenakan kepadatan jam mengajar bagi Guru harus melayani berlangsungnya belajar mengajar proses tatap muka di hadapan para murid dibatasai, apalagi dalam Tahun ini (2020), adalah Tahun krisis kesehatan secara global yang sangat dibatasi untuk aktif berkegiatan proses belajar mengajar secara pertemuan tatap muka antara guru dan murid di dalam kelas maupun di luar kelas, batasan menjaga jarak "Social Destantion" dan bertahan tinggal di rumah "Lock Down" di masa pandemi Covid 19 dikhawatirkan dan wajib diwaspadai.

\section{KESIMPULAN}

Pelatihan yang dilaksanakan di Sekolah Dasar Inpres Unggulan BTN Pemda Makassar dapat menerapkan pengembangan media pendidikan seni rupa tingkat Sekolah tersebut dan dapat berperan sebagai landasan utama untuk mudahnya proses pembimbingan, melatih dan mengembangkan kemampuan kognitif, afektif dan psikomotorik secara mendasar dan untuk mencapai tingkat emosional serta spiritual di dalam memperoleh hasil berbagai materi terapan model - model pembelajaran aktif, inovatif, kreatif, serta dapat membangkitkan daya minat belajar mata pelajaran Seni Budaya (Seni Rupa) yang menyenangkan. Di sinilah letak peran sebagai Guru Kelas mengajar mengajar mata pelajaran Seni Rupa, dalam penyajian mata pelajaran seni rupa (menggambar sketsa dan melukis teknik Fresco), Guru Sekolah Dasar Inpres Unggulan BTN Pemda Makassar, harus mampu mamahami arti pemahaman kreatif dan inovatif yang berkesan bagi peserta didik, menjadi keutamaan untuk dapat mengembangkan pembelajaran mata pelajaran seni rupa. Guru dan murid dapat proaktif, proses pembelajaran seni rupa yang inovatif yang diterapkan di Sekolah tingkat Sekolah Dasar Inpres Unggulan BTN Pemda Makassar selayaknya juga ikut serta mengikuti gerak berkembangnya ilmu pengetahuan seni rupa sesuai berkembangnya karya- karya seni rupa ditingkat Sekolah Dasar Inpres Unggulan BTN Pemda Makassar lainnya yang setara dan 
dapat tumbuh berkembang sesuai kurikulumnya yaitu mata pelajaran Seni Budaya khususnya bidang mata pelajaran Seni Budaya (seni rupa) di Sulawesi Selatan.

\section{DAFTAR PUSTAKA}

Adjat Sakri, 1990, Pendidikan Seni Rupa : Buku Guru Sekolah Menengah Atas, penerbit Departemen Pendidikan dan Kebudayaan, Jakarta.

Arief S.Sadiman, dkk, 1986, Media Pendidikan, Penerbit CV. Rajawali, Jakarta

Atmaja, Muchtar Kusuma, 1991, Perjalanan Seni Rupa Indonesia, Pantia KIAS 1990/1991, Proyek Penelitian dan Pencatatan Kebudayaan Daerah Depdikbud, Jakarta.

Hartoko, Dick, Manusia dan Seni, Yayasan Kanisius, Yogyakarta, 1984

https//www.dicto id. teknik melukis al fresco, 3 April 2018).

Iskandar, Popo, Alam Pikiran Seniman, Aksara Indonesia, Jakarta, 2000

Kempers, 1959, Ancient Indonesian Art, Harvard Univ. Press.

M. Zainuddin, 2001, Praktikum, Penerbit Pusat antar Universitas untuk Peningkatan dan Pengembangan Aktivitas Instruksional. Direktorat Jenderal Pendidikan Tinggi Departemen Pendidikan Nasional, Jakarta

Read, Herbert, Pengertian Seni, Terjemahan Soedarso Sp., Sekolah Tinggi Seni Rupa Indonesia Yogyakarta, 1973

Read, Herbert, Seni: Arti dan Problematiknya, Duta Wacana University Press, Yogyakarta, 2000

Salam, Sofyan, Seni Rupa Mimesis dan Modern/Kontemporer di Sulawesi Selatan (Sebuah Pengantar Tentang Perjalanan dan Persoalannya), DKSS Makassar, Makassar, 2000

Soedarso Sp., Beberapa Catatan Tentang Perkembangan Kesenian Kita, BP.ISI Yogyakarta,Yogyakarta, 1991

Soedarso Sp., Tinjauan Seni: Sebuah Pengantar Untuk Apresiasi Seni, Suku Dayar Sana Yogyakarta, 1980
Subiantoro, Benny, 2002. "Metode Penciptaan seni membangkitkan Kreasi- Inovasi- Imajinasi dan Interpretasi", Tugas Mata Kuliah: Metode Penciptaan Seni Program Pascasarjana Penciptaan Seni Institut Seni Indonesia Yogyakarta.

Trini Prasasti, dkk, 2001, Media Sederhana, Penerbit Pusat antar Universitas untuk Peningkatan dan Pengembangan Aktivitas Instruksional. Direktorat Jenderal Pendidikan Tinggi Departemen Pendidikan Nasional, Jakarta 